\title{
Left ventricular thrombus and Takotsubo cardiomyopathy in a patient receiving electroconvulsive therapy: Case report and literature review
}

\author{
Shiv Kumar Agarwal MD¹, Naga Venkata Krishna Pothineni $M D^{1}$, Jason Payne $M D^{1}$,

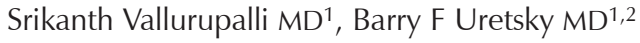

\begin{abstract}
SK Agarwal, NVK Pothineni, J Payne, S Vallurupalli, BF Uretsky. Left ventricular thrombus and Takotsubo cardiomyopathy in a patient receiving electroconvulsive therapy: Case report and literature review. Curr Res Cardiol 2015;2(4):202-204.

Cardiovascular side effects after electroconvulsive therapy (ECT) are rare but can potentially lead to significant morbidity and mortality. The authors present a case involving a 67-year-old woman who developed Takotsubo cardiomyopathy (TC) with left ventricular (LV) thrombus eight days after her last ECT. She received six ECT treatments for active suicidal ideation after prophylaxis with oral metoprolol and intravenous esmolol and was discharged home. She presented to the emergency room with altered mental status, where an electrocardiogram revealed anterior
\end{abstract}

Clectroconvulsive therapy (ECT) is used in the management of $\mathrm{E}_{\text {patients with major depression and significant functional impair- }}$ ment not responsive to pharmacological and/or psychotherapeutic interventions. ECT may also be used as a first-line treatment option for severe depression with psychotic features, catatonia, suicide risk or in those who are nutritionally compromised as a result of refusing food (1). The safety and efficacy of ECT has been demonstrated by numerous studies. Cardiovascular side effects are rare but may produce significant morbidity and mortality (2). Case reports of stress-induced cardiomyopathy or Takotsubo cardiomyopathy (TC) have been described after ECT but the event/diagnosis usually occurs within hours after treatment. We present a case of TC with left ventricular (LV) apical thrombus that may have occurred as late as eight days following ECT. We describe the present case and review the medical literature for all other cases after ECT.

\section{CASE PRESENTATION}

A 67-year-old woman with a history of major depression and obsessivecompulsive disorder and no known cardiac disease was brought to the emergency department by a friend due to acute memory disturbance and behavioural changes. She had recently been hospitalized for four weeks for major depression with active suicidal ideation and was treated with six treatments of ECT (last treatment eight days before presentation). She had been pretreated with beta-blockers (oral metoprolol and intravenous [IV] esmolol) before each ECT. Her history was not considered to be reliable because of some level of disorientation, but she denied present or past chest pain, or shortness of breath. Except for a rapid heart rate (102 beats/min) physical examination was unremarkable. Electrocardiograhy (ECG), as part of routine admission workup, revealed sinus tachycardia with $>2 \mathrm{~mm}$ ST elevations in leads II, III, avF and V3-V6, compatible with an ST segment elevation myocardial infarction. These ECG findings were new compared with an ECG four weeks earlier. The patient was taken for emergent cardiac catheterization, which showed normal coronary arteries. Left ventriculogram
ST segment elevation compatible with an ST segment elevation myocardial infarction. Emergent coronary angiogram was normal. Left ventriculogram showed characteristic apical dyskinesis compatible with TC. Echocardiogram revealed an apical LV thrombus. The patient was placed on anticoagulant therapy. Repeat echocardiogram eight weeks later showed normal LV function with resolution of thrombus. Physicians managing ECT patients should be aware of the possibility of TC with LV thrombus as a complication of this procedure. The authors review the medical literature and provide recommendations for peri-ECT management of patients with previous TC.

Key Words: Electroconvulsive therapy; LV thrombus; Takotsubo cardiomyopathy

showed apical dyskinesis and hypercontractile left ventricular (LV) base compatible with so-called Takotsubo cardiomyopathy also known as the apical ballooning syndrome or stress-induced cardiomyopathy (Figures $1 \mathrm{~A}$ and $1 \mathrm{~B})$. An echocardiogram the next day showed a large ovoid apical left ventricular thrombus (Figure 1C). She was anticoagulated with warfarin. Eight weeks later, echocardiography revealed normal LV

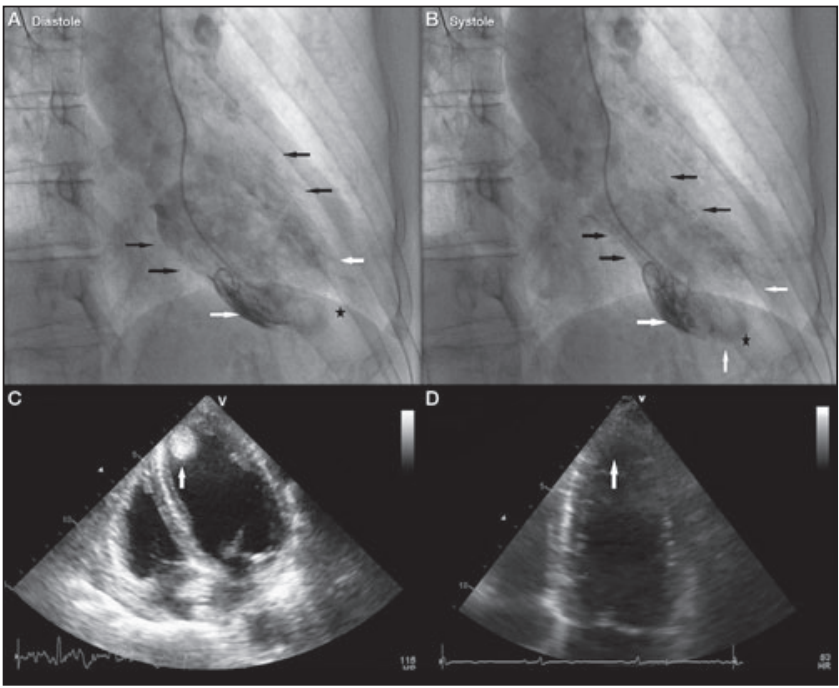

Figure 1) A Left ventriculogram in diastole showing normal appearing left ventricular (LV) endocardium at base (black arrows) and apex (white arrows) of heart with apical thrombus (star). B Left ventriculogram in systole showing normal contracting base (black arrows) with akinesis and ballooning of apex (white arrows) suggestive of Takotsubo cardiomyopathy. C Echocardiogram showing $L V$ apical thrombus (white arrow) in apical four-chamber view at initial presentation. D Echocardiogram showing resolution of apical thrombus (white arrow) in the apical four-chamber view eight weeks later

\footnotetext{
${ }^{1}$ Department of Cardiovascular Medicine, University of Arkansas for Medical Sciences; ${ }^{2}$ Central Arkansas Veterans Affair Health System, Little Rock, Arkansas, USA

Correspondence: Dr Shiv Kumar Agarwal, Department of Cardiovascular Medicine, S3/05, University of Arkansas for Medical Sciences, 4301 West Markham Street, mail slot \#532, Little Rock, Arkansas 72205, USA. Telephone 501-686-7882, fax 501-686-6439,

e-mail drshivkumar.agarwal@gmail.com
} 
TABLE 1

Characteristics of published case reports of Takotsubo cardiomyopathy (TC)

\begin{tabular}{|c|c|c|c|c|c|c|c|c|c|c|c|}
\hline $\begin{array}{l}\text { Author } \\
\text { (reference), } \\
\text { year }\end{array}$ & $\begin{array}{l}\text { Age, } \\
\text { years }\end{array}$ & $\begin{array}{l}\text { Cardiac } \\
\text { history }\end{array}$ & $\begin{array}{l}\text { Previous } \\
\text { ECT treat- } \\
\text { ments, } n\end{array}$ & $\begin{array}{l}\text { Initial sign/ } \\
\text { symptom }\end{array}$ & $\begin{array}{l}\text { Beta-blocker } \\
\text { use during } \\
\text { ECT }\end{array}$ & $\begin{array}{l}\text { Time to } \\
\text { onset of } \\
\text { symptoms } \\
\text { from ECT }\end{array}$ & Management & $\begin{array}{l}\text { Repeat } \\
\text { ECHO }\end{array}$ & $\begin{array}{l}\text { Prophylactic } \\
\text { medication on } \\
\text { repeat ECT }\end{array}$ & $\begin{array}{l}\text { Duration } \\
\text { to repeat } \\
\text { ECT }\end{array}$ & $\begin{array}{l}\text { ECTs } \\
\text { after TC, n }\end{array}$ \\
\hline $\begin{array}{l}\text { Zhu et al (15), } \\
1992\end{array}$ & 77 & No & 1 & $\begin{array}{l}\text { ECG changes; } \\
\text { no chest pain }\end{array}$ & NR & Immediate & NR & 4 days & IV labetolol & 6 months & 2 \\
\hline $\begin{array}{l}\text { Eitzman et al } \\
(6), 1994\end{array}$ & 76 & No & 1 & $\begin{array}{l}\text { ECG changes; } \\
\text { no chest pain }\end{array}$ & NR & Immediate & Nifedipine $90 \mathrm{mg}$ & 6 days & $\begin{array}{l}\text { Oral nifedipine } \\
90 \text { mg/day }\end{array}$ & NR & NR \\
\hline $\begin{array}{l}\text { Ring et al (12), } \\
1996\end{array}$ & 41 & No & 1 & $\begin{array}{l}\text { Cardiogenic } \\
\text { shock }\end{array}$ & $\begin{array}{l}\text { Propranolol } \\
\text { (home } \\
\text { medication) }\end{array}$ & Immediate & $\begin{array}{l}\text { Ionotropic support } \\
\text { with dopamine, } \\
\text { dobutamine and } \\
\text { epinephrine; IABP }\end{array}$ & 1 week & NR & NR & NR \\
\hline
\end{tabular}

\begin{tabular}{|c|c|c|c|c|c|c|c|c|c|c|c|}
\hline $\begin{array}{l}\text { O'Reardon } \\
\text { et al (11), } \\
2008\end{array}$ & 45 & No & 3 & Chest pain & NR & Immediate & $\begin{array}{l}\text { Metoprolol } \\
100 \text { mg daily }\end{array}$ & 4 days & NR & NR & NR \\
\hline $\begin{array}{l}\text { Littlejohn et al } \\
\text { (10), } 2008\end{array}$ & 71 & No & 11 & Chest pain & $\begin{array}{l}\text { Metoprolol } \\
\text { (home medi- } \\
\text { cation) }\end{array}$ & $3 \mathrm{~h}$ to $4 \mathrm{~h}$ & ACEI & 4 months & $\begin{array}{l}\text { Oral metoprolol } \\
\text { and IV labetolol }\end{array}$ & 9 months & 25 \\
\hline $\begin{array}{l}\text { Go et al (7), } \\
2009\end{array}$ & 50 & No & 3 & $\begin{array}{l}\text { Cardiogenic } \\
\text { shock }\end{array}$ & NR & Immediate & $\begin{array}{l}\text { Amlodipine; } \\
\text { metoprolol }\end{array}$ & 5 days & NR & NR & NR \\
\hline $\begin{array}{l}\text { Go et al (7), } \\
2009\end{array}$ & 49 & No & 1 & $\begin{array}{c}\text { Dysnea/pulmo- } \\
\text { nary edema }\end{array}$ & NR & 'Shortly' & Furosemide; ACEI & 5 days & NR & NR & NR \\
\hline $\begin{array}{l}\text { Kent et al (9), } \\
2009\end{array}$ & 71 & No & 16 & Chest pain & NR & $\begin{array}{c}\text { Several } \\
\text { hours }\end{array}$ & $\begin{array}{l}\text { ASA; clopidogrel; } \\
\text { metoprolol }\end{array}$ & 1 month & IV esmolol & 1 month & 19 \\
\hline $\begin{array}{l}\text { Chandra et al } \\
(5), 2009\end{array}$ & 70 & $\begin{array}{l}\text { MV } \\
\text { repair }\end{array}$ & 1 & $\begin{array}{l}\text { ECG changes; } \\
\text { no chest pain }\end{array}$ & NR & Immediate & NR & 6 weeks & NR & NR & NR \\
\hline $\begin{array}{l}\text { Serby et al } \\
\text { (14), } 2010\end{array}$ & 90 & No & $>100$ & $\begin{array}{l}\text { ECG changes; } \\
\text { no chest pain }\end{array}$ & NR & Immediate & Warfarin & NR & NR & NR & NR \\
\hline $\begin{array}{l}\text { Beach et al } \\
\text { (3), } 2010\end{array}$ & 52 & No & 1 & Chest pain & NR & 'Shortly' & $\begin{array}{l}\text { ASA; metoprolol; } \\
\text { morphine }\end{array}$ & 5 months & NR & NR & NR \\
\hline $\begin{array}{l}\text { Celano et al } \\
(4), 2011\end{array}$ & 76 & No & 11 & Chest pain & NR & Immediate & ASA; atenolol & 3 days & IV labetolol & 1.5 months & 19 \\
\hline $\begin{array}{l}\text { Grubisha et al } \\
(8), 2014\end{array}$ & 31 & No & $>50$ & Hypotension & NR & $\begin{array}{c}\text { Several } \\
\text { hours }\end{array}$ & Beta-blocker* & $\begin{array}{l}\text { Few } \\
\text { weeks }\end{array}$ & NR & NR & NR \\
\hline $\begin{array}{l}\text { Narayanan } \\
\text { et al (13), } \\
2014\end{array}$ & 74 & No & $\begin{array}{l}8 \text { (5 years } \\
\text { before } \\
\text { current } \\
\text { ECT) }\end{array}$ & $\begin{array}{l}\text { Epigastric } \\
\text { discomfort, } \\
\text { SOB, ECG } \\
\text { changes }\end{array}$ & $\begin{array}{l}\text { Bisoprolol } \\
\text { (home } \\
\text { medication) }\end{array}$ & 'Shortly' & $\begin{array}{l}\text { ASA, clopidegrel, } \\
\text { bisoprolol, } \\
\text { lisinopril }\end{array}$ & $\begin{array}{l}\text { Not } \\
\text { reported }\end{array}$ & NR & NR & NR \\
\hline
\end{tabular}

*Specific drug not reported. ACEI Angiotensin-converting enzyme inhibitor; ASA Acetylsalicylic acid; ECG Electrocardiogram; ECT Electroconvulsive therapy; ECHO Echocardiography; IABP Intra-aortic balloon pump; IV Intravenous; MV Mitral valve; NA Not applicable; NR Not reported; SOB Shortness of breath

systolic function with resolution of the apical dyskinesis and apical thrombus (Figure 1D). Warfarin was discontinued.

\section{DISCUSSION}

TC is characterized by ST segment elevation on ECG, angiographically normal coronary arteries and LV apical dyskinesis (which, to Japanese investigators who first described the syndrome, resembled an octopus net or 'tako-tsubo'). TC is a rare complication following ECT, with only a handful of reported cases in literature (3-15). To the best of our knowledge, the present case is the first to describe LV thrombus associated with TC in this setting, suggesting that prolongation of the apical dyskinesis provided a favourable environment for thrombus development. There have been 14 cases reported consistent with features of TC: nine described specifically as TC $(3-5,8-11,13,14)$, four described as myocardial stunning but with features of TC $(6,7,15)$, and one with TC and cardiogenic shock (12). All cases except one were in middle-age or elderly women, similar to our patient. The one exception was in a young male with a history of seizure disorder (8). The 14 reported cases are presented in Table 1.

The reported initial clinical presentation varied, some presented with only ECG changes and no cardiac symptoms $(5,6,14,15)$ while others developed chest pain $(3,4,9-11)$ or shortness of breath or even cardiogenic shock $(7,12)$. All patients recovered and no deaths were reported. Our patient did not have any cardiac symptoms (although this was considered to be unreliable considering her altered mental status) but had electrocardiographic ST elevation. A unique aspect of our case is the presence of LV thrombus, which is uncommon and has not been reported in other cases of TC after ECT. Our patient presented eight days after the last ECT giving sufficient time for thrombus formation, while all other cases reported were diagnosed within a few hours following ECT. Stasis for an extended period in akinetic or dyskinetic areas of the myocardium creates a milieu for thrombogenesis.

Various mechanisms have been proposed for the pathogenesis of TC including epicardial coronary artery vasospasm, coronary microvascular impairment, direct catecholamine-induced myocyte injury and/or neurogenic stunned myocardium (16). Currently, a favoured hypothesis is catecholamine-induced injury to myocardium in some way not yet clarified. It is interesting that beta-adrenoceptors are most densely distributed at the apical myocardium, which may explain the regional nature of stunning (17). Beta-blockers may attenuate the preconditions to the development of TC. However, of the 14 reported cases, three (21\%) developed TC despite being 
treated with an oral beta-blocker $(10,12,13)$. All of these patients were on a beta-blocker at home, which was continued though ECT sessions. Our patient was unique insofar as both oral and IV betablockers were used as pre-treatment, suggesting a high degree of betareceptor blockade before ECT.

There are no specific guidelines for the management of TC. Early treatment is similar to that in ST segment elevation myocardial infarction patients with coronary obstructive disease, including acetylsalicylic acid. However, in view of frequent ventricular recovery and normal coronary arteries, chronic treatment strategies used in patients with coronary artery disease are frequently unnecessary for TC. LV systolic dysfunction should be treated with guideline-based medical therapy (beta-blockers, angiotensin-converting enzyme inhibitors). Anticoagulation may be necessary if thrombus develops, as in the present case, but can be discontinued if the thrombus resolves as it did in the present case. Repeat echocardiography in one to three months is suggested after initial diagnosis to assess for improvement in LV function and resolution of LV thrombus.

There have been no studies assessing the safety of repeat ECT in patients who developed TC. Four TC patients successfully underwent

\section{REFERENCES}

1. Practice Guideline For The Treatment of Patients With Major Depressive Disorder. American Psychiatric Association. 2010 $<$ http://psychiatryonline.org/pb/assets/raw/sitewide/practice guidelines/guidelines/mdd.pdf> (Accessed November 6, 2014).

2. Yu SW, Vallurupalli S, Arnoldi J, Holloway R. Atrioventricular dissociation after electroconvulsive therapy. Cardiol Res Pract 2011;2011:4.

3. Beach SR, Wichman CL, Canterbury RJ. Takotsubo cardiomyopathy after electroconvulsive therapy. Psychosomatics 2010;51:432-6.

4. Celano CM, Torri A, Seiner S. Takotsubo cardiomyopathy after electroconvulsive therapy: A case report and review. J ECT 2011;27:221-3.

5. Chandra PA, Golduber G, Chuprun D, Chandra AB. Tako-tsubo cardiomyopathy following electroconvulsive therapy. J Cardiovasc Med (Hagerstown) 2009;10:333-5.

6. Eitzman DT, Bach DS, Rubenfire M. Management of myocardial stunning associated with electroconvulsive therapy guided by hyperventilation echocardiography. Am Heart J 1994;127(4 Pt 1):928-9.

7. Go O, Mukherjee R, Bhatta L, Carhart R Jr, Villarreal D. Myocardial stunning after electroconvulsive therapy in patients with an apparently normal heart. J ECT 2009;25:117-20.

8. Grubisha M, Gopalan P, Azzam PN. Takotsubo cardiomyopathy in a young man after maintenance electroconvulsive therapy and clozapine initiation: A case report. J ECT 2014.

9. Kent LK, Weston CA, Heyer EJ, Sherman W, Prudic J. Successful retrial of ECT two months after ECT-induced Takotsubo cardiomyopathy. Am J Psychiatry 2009;166:857-62. repeat ECT without recurrence (Table 1). Only one patient reported by Zhu et al (15) developed a second episode of TC after ECT while on nitrates and diltiazem. This patient later tolerated another ECT session on IV labetalol pretreatment. There has been no standard beta-blocker prophylaxis treatment regimen for repeat ECT. However, based on literature review, we recommend significant beta blockade as pretreatment unless contraindicated. Efficacy of pretreatment may be assessed by clear heart rate slowing compared with baseline, and may be accomplished either with adequate oral doses or oral doses supplemented by intravenous beta-blocker at the time of ECT. Treatment of depression after TC with subsequent ECT should be individualized and carefully attempted using a multidisciplinary approach involving a cardiologist, as well as discussion of risks and benefits with patient and family. Peri-ECT beta-blocker therapy is crucial and the patient should be closely monitored. Further studies are needed to identify the patients who are at risk for TC after ECT.

DISCLOSURES: The authors have no financial disclosures or conflicts of interest to declare.

10. Littlejohn FC, Syed O, Ornstein E, Connolly ES, Heyer EJ.

Takotsubo cardiomyopathy associated with anesthesia:

Three case reports. Cases J 2008;1:227.

11. O'Reardon JP, Lott JP, Akhtar UW, Cristancho P, Weiss D, Jones N. Acute coronary syndrome (Takotsubo cardiomyopathy) following electroconvulsive therapy in the absence of significant coronary artery disease: Case report and review of the literature. J ECT 2008;24:277-80.

12. Ring BS, Parnass SM, Shulman RB, Phelan J, Khan SA. Cardiogenic shock after electroconvulsive therapy. Anesthesiology 1996;84:1511-3.

13. Narayanan A, Russell MD, Sundararaman S, Shankar KK, Artman B. Takotsubo cardiomyopathy following electroconvulsive therapy: An increasingly recognised phenomenon. BMJ Case Rep 2014;2014.

14. Serby MJ, Lantz M, Chabus BI, Bernay LJ. Takotsubo cardiomyopathy and electroconvulsive treatments: A case study and review. Int J Psychiatry Med 2010;40:93-6.

15. Zhu WX, Olson DE, Karon BL, Tajik AJ. Myocardial stunning after electroconvulsive therapy. Ann Intern Med 1992;117:914-5.

16. Veillet-Chowdhury M. Takotsubo cardiomyopathy: A review. Acute Card Care.2014;16:15-22.

17. Lyon AR, Rees PSC, Prasad S, Poole-Wilson PA, Harding SE. Stress (Takotsubo) cardiomyopathy[mdash]a novel pathophysiological hypothesis to explain catecholamine-induced acute myocardial stunning. Nat Clin Pract Cardiovasc Med 2008;5:22-9. 